\title{
High carbon demand of dominant
} macrozoobenthic species indicates their central role in ecosystem carbon flow in a sub-Arctic fjord

\author{
Martin Emil Blicher ${ }^{1,2, *}$, Mikael Kristian Sejr ${ }^{2}$, Søren Rysgaard ${ }^{1}$ \\ ${ }^{1}$ Greenland Institute of Natural Resources, Kivioq 2, Box 570, 3900 Nuuk, Greenland \\ ${ }^{2}$ National Environmental Research Institute, Vejlsøvej 25, 8600 Silkeborg, Denmark
}

\begin{abstract}
The sea urchin Strongylocentrotus droebachiensis and the scallop Chlamys islandica dominate the shallow macrobenthic community in Kobbefjord, southwest Greenland $\left(64^{\circ} 09^{\prime} \mathrm{N}\right.$, $51^{\circ} 36^{\prime} \mathrm{W}$ ). Densities were estimated from seafloor photographs along 3 depth transects (0 to $120 \mathrm{~m}$ ). Annually formed growth bands in the interambulacral plates of $S$. droebachiensis and in the ligament of $C$. islandica were used to establish growth functions. Growth data combined with size frequencies, size-mass relationships and fjord bathymetry were used to estimate annual production and carbon demand of the 2 species in order to assess their ecological importance. Distributions of the 2 species were strongly related to depth and partially separated. Averaged over all depths, the densities were estimated at 4.9 ind. $\mathrm{m}^{-2}$ (range: 0 to 38 ind. $\mathrm{m}^{-2}$ ) and 5.6 ind. $\mathrm{m}^{-2}$ (range: 0 to 57 ind. $\mathrm{m}^{-2}$ ) for $S$. droebachiensis and C. islandica, respectively. Maximum ages of $S$. droebachiensis and C. islandica were estimated at 24 and $39 \mathrm{yr}$, respectively. Somatic growth of both species was relatively slow, and their reproductive output constituted the bulk ( 62 to $73 \%$ ) of their total annual production. Mean annual production in the fjord was estimated at $3.2 \mathrm{~g}$ ash-free dry weight (AFDW) $\mathrm{m}^{-2}$ for $S$. droebachiensis

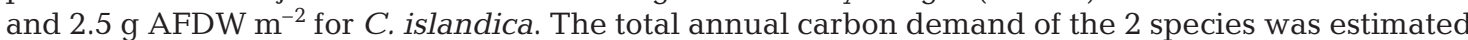
at $30.6 \mathrm{~g} \mathrm{C} \mathrm{m}^{-2}$, corresponding to $21-45 \%$ of annual pelagic primary production in this area. In conclusion, S. droebachiensis and C. islandica play important roles in carbon cycling of Kobbefjord and can be regarded as central species of the shallow benthic community. A comparison with literature estimates of annual macrozoobenthic carbon demand in Arctic and sub-Arctic habitats revealed that the macrozoobenthic carbon demand in Kobbefjord is relatively high and that annual carbon requirements of macrozoobenthos in the Arctic seem to reflect the level of pelagic primary production.
\end{abstract}

KEY WORDS: Macrobenthos · Strongylocentrotus droebachiensis · Chlamys islandica · Production · Carbon demand · Kobbefjord · Greenland · Climate

\section{INTRODUCTION}

Of all oceans the Arctic Ocean contains the largest shelves $(<50$ to $300 \mathrm{~m})$, which make up more than $\sim 50 \%$ of the Arctic Ocean area and $\sim 20 \%$ of all shallow continental shelves in the world (Menard \& Smith 1966). Thus, benthic communities in the Arctic have traditionally been considered important for overall ecosystem carbon cycling, but there are still only a few estimates of the production and carbon requirements of macrobenthos (Grebmeier et al. 1989, Rysgaard \&
Nielsen 2006), and several studies of Arctic macrobenthos have considered biomass as a proxy for production and carbon demand (e.g. Grebmeier et al. 2006a). However, this interpretation is supported by the fact that macrobenthic biomass in parts of the Arctic to some degree reflects the spatial variation in primary production in the overlying water column or the amount of sediment chlorophyll (Grebmeier et al. 2006a), which, in combination with physiological and theoretical studies (e.g. Clarke 1988, Clarke \& Fraser 2004, Sejr et al. 2004), suggests that the activity of mac- 
robenthic communities in polar areas is primarily limited by food availability and to a lesser extent by low temperature. The relation between macrobenthic carbon demand and standing stock is not necessarily straightforward, however. It is influenced by species composition, age structure of populations, growth rate, reproductive output and rate of metabolism and, indirectly, by temperature, habitat structure and disturbance level. Estimates of macrobenthic production and carbon demand in the Arctic are therefore essential for at least 2 reasons. (1) They generate baseline studies that describe population dynamics and quantify the role of macrobenthos in marine carbon cycling under the present environmental and climatic conditions. This is important for both the existing and future understanding of ecological structures in Arctic marine ecosystems. (2) They allow evaluation of the importance of different environmental parameters, biotic as well as abiotic, for benthic production in polar areas. Both perspectives are important in the light of future global warming, which is predicted to be particularly intense in the Arctic (e.g. ACIA 2005). Future atmospheric warming will reduce the sea ice cover and consequently increase the amount of light reaching the water column. Increased irradiation has the potential to positively affect primary production in large areas, especially in the high-Arctic (Rysgaard et al. 1999, Wassmann et al. 2006, Arrigo et al. 2008) and thus potentially extending the growth season for benthic secondary producers. A study of individual growth of the sea urchin Strongylocentrotus droebachiensis along an existing climate gradient in Greenland revealed a positive correlation between individual growth performance and the length of the sea ice-free period during summer. This trend in secondary production was suggested to be a result of geographical differences in marine primary production and, hence, food level, which might correspond to the temporal development in a global warming scenario (Blicher et al. 2007). Still, a more detailed understanding of the relationship between primary production and benthic secondary production at the community level is necessary, and may have important implications for predictions of future ecosystem structure in the large shallow areas in the Arctic.

Kobbefjord, one of the numerous fjords in Southwest Greenland, is a part of the Godthåbsfjord system, which has been chosen as a study area in a recently initiated long-term climate-monitoring program focusing on ecosystem structures and dynamics in the subArctic (www.nuuk-basic.dk). Dredge collections conducted in an earlier pilot study in Kobbefjord indicated that the sea urchin Strongylocentrotus droebachiensis (O. F. Müller) and the scallop Chlamys islandica (O. F. Müller) dominate the shallow macrozoobenthic com- munity in terms of biomass (M. E. Blicher unpubl. data). The objective of the present study was to quantify the density and biomass of these 2 epifaunal species and estimate their annual production and carbon demand in Kobbefjord, and compare it to other estimates of macrozoobenthic carbon demand in the Arctic region. Annual pelagic primary production in Kobbefjord is within the range of 75 to $160 \mathrm{~g} \mathrm{C} \mathrm{yr}^{-1}$ (Smidt 1979, Mikkelsen et al. 2008a,b, Rysgaard et al. 2008), which is high compared to in other regions of Greenland and in the Arctic in general (Rysgaard et al. 1999). Production and carbon demand of macrozoobenthos in Kobbefjord was expected to reflect the pattern in primary production. We therefore hypothesized that carbon demand of the dominant macrozoobenthic species in Kobbefjord is high compared to other estimates of macrozoobenthic carbon demand in the Arctic region.

\section{MATERIALS AND METHODS}

The study was conducted in 2007 and 2008 in the outer region of Kobbefjord, which is a part of the Godthåbsfjord system in sub-Arctic Southwest Greenland (Fig. 1). Kobbefjord is $\sim 17 \mathrm{~km}$ long and 0.8 to $2 \mathrm{~km}$ wide. The innermost part of the fjord is usually sea ice covered during winter, with extensive interannual variation. Sea surface temperature ranges from $-1.5^{\circ} \mathrm{C}$ during winter to a maximum of $\sim 8^{\circ} \mathrm{C}$ in late summer. The amount of chlorophyll $a$ in the photic zone varies from very low concentrations in winter $\left(<0.1 \mu \mathrm{g} \mathrm{l}^{-1}\right)$ to maximum values of up to $3-5 \mathrm{\mu g} \mathrm{l}^{-1}$ during blooms, which can occur in both spring and late summer (M. E. Blicher unpubl. data). The present study focuses on the fjord's outer region of $\sim 16 \mathrm{~km}^{2}$ (Fig. 1b).

Species density. A series of high-resolution digital photographs of the sea floor was obtained along 3 transects in depth intervals of $10 \mathrm{~m}$ each, between 0 and $120 \mathrm{~m}$ depth (Fig. 1b). Lasers were attached to the system to scale the images. A total of 288 digital photographs, each covering $\sim 0.5 \mathrm{~m}^{2}\left(\sim 141 \mathrm{~m}^{2}\right.$ in total), was used to quantify the density of the sea urchin Strongylocentrotus droebachiensis and the scallop Chlamys islandica.

Collection and processing. Strongylocentrotus droebachiensis and Chlamys islandica were collected using a triangular dredge (mesh size: $1 \times 1 \mathrm{~cm}$ ) at 50 to $60 \mathrm{~m}$ depth in outer Kobbefjord. Sea urchins were also collected at 5 to $15 \mathrm{~m}$ depth and included in a biomass analysis. Specimens where frozen $\left(-18^{\circ} \mathrm{C}\right)$ immediately after collection and kept frozen until analysis. Maximum diameter of sea urchins and shell height of scallops were measured to the nearest $0.1 \mathrm{~mm}$ using Vernier callipers, and wet weight (WW) was determined to the nearest $0.01 \mathrm{~g}$. Specimens were carefully 


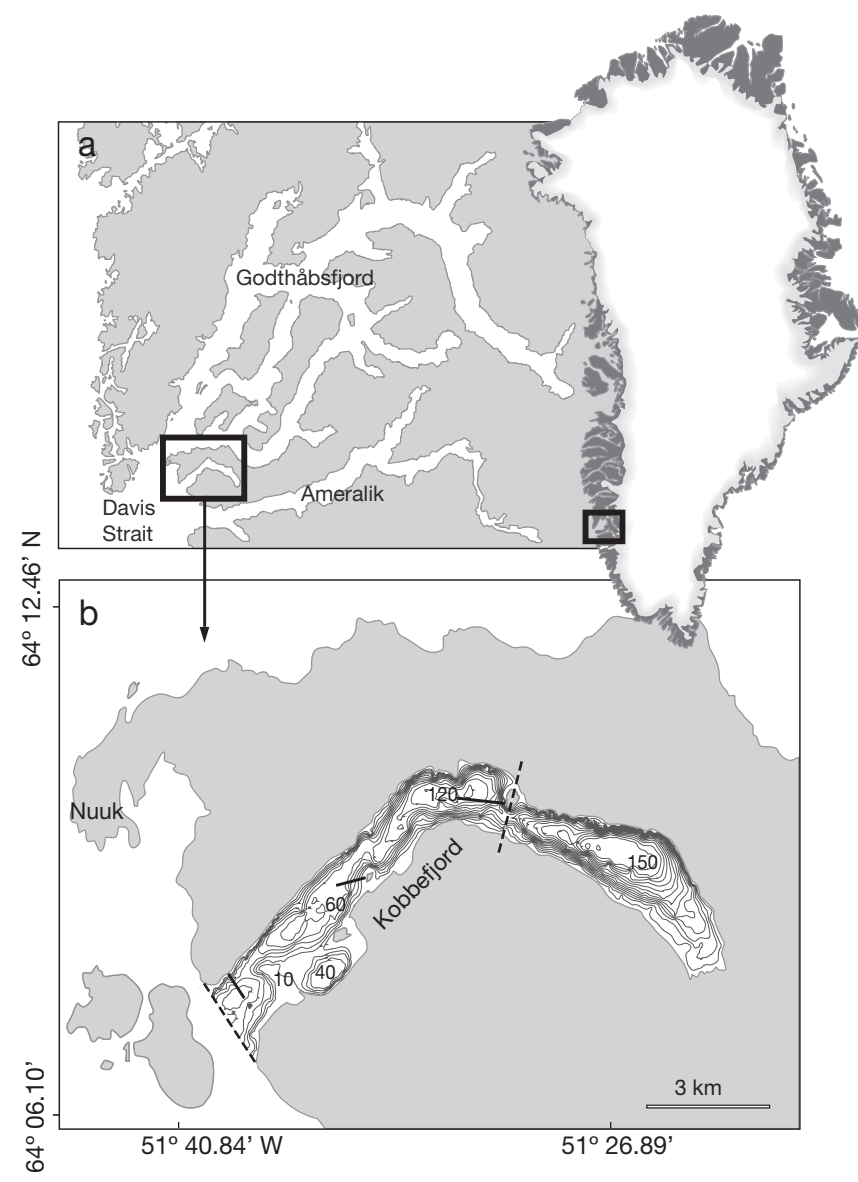

Fig. 1. (a) Location of the study area in Greenland. (b) Enlargement of Kobbefjord. The outer region, where we conducted the dredge collections and underwater photo transects, is bound by dashed lines; $10 \mathrm{~m}$ depth curves are shown (see 'Results')

dissected into gonads and somatic tissue to establish relations between biomass and size. Gonad and somatic dry weight (DW) and ash-free dry weight (AFDW), respectively, were determined by drying at $60^{\circ} \mathrm{C}$ for at least $24 \mathrm{~h}$ until constant weight, followed by ignition at $550^{\circ} \mathrm{C}$ in a muffle furnace for $12 \mathrm{~h}$.

For Strongylocentrotus droebachiensis we fitted a power function to gonad mass-at-diameter data:

$$
M_{\mathrm{g}(S d)}=a D_{t}^{b}
$$

where $M_{\mathrm{g}(\mathrm{Sd})}$ is the individual gonad mass (g AFDW) of $S$. droebachiensis at diameter $D_{t}(\mathrm{~mm})$, and $a$ and $b$ are coefficients in the regression. We used the sigmoidal Gompertz function to describe the relationship between gonad mass $M_{\mathrm{g}(\mathrm{Ci})}$ and shell height $\mathrm{SH}_{t}(\mathrm{~mm})$ of Chlamys islandica:

$$
M_{\mathrm{g}(C i)}=M_{\mathrm{g}(\mathrm{C} i) \infty} \mathrm{e}^{-\exp \left[-K\left(S H_{t}-S H *\right)\right]}
$$

where $M_{\mathrm{g}(C i)_{\infty}}$ is the maximum individual gonad mass (g AFDW), $K$ defines the slope and $S H^{*}$ is the shell height (mm) at curve inflexion. As for all non-linear regressions in the present study, we used the iterative Levenberg-Marquardt algorithm (Marquardt 1963).

Age. We determined individual age using separate methods for the 2 species. For Strongylocentrotus droebachiensis we used a combination of the methods described by Jensen (1969), Pearse \& Pearse (1975) and Brey (1991). Individuals were carefully cut along the ambitus with a scalpel, after which the intestine, gonads and Aristotle's lantern were removed. We bleached the echinoid skeleton in a $5 \%$ sodium hypochlorite $(\mathrm{NaOCl})$ solution for 5 to $10 \mathrm{~min}$ to remove organic tissue. The skeleton was then dried at $60^{\circ} \mathrm{C}$ for $12 \mathrm{~h}$ and charred in a muffle furnace at $300^{\circ} \mathrm{C}$ for 5 to $10 \mathrm{~min}$. We carefully polished the interambulacral plates with carborundum paper (800 grit) on the outside of the plates after which they were placed in xylene. In this way, growth zones in the skeletal plates, consisting of alternating translucent winter zones and opaque summer growth zones were made visible. Using a dissecting microscope we counted growth zones in the oldest interambulacral plates closest to the mouth (Nos. 1 to 7 ), which contain the first year's growth zone and supplemented it with counts in younger plates as described by Blicher et al. (2007).

The age of Chlamys islandica was determined by the method described by Johannessen (1973). We carefully removed the dark elastic part of the shell ligament, exposing the underlying hard part, where growth zones, consisting of alternating dark winter lines and pale summer growth increments, became visible. We estimated age by counting the narrow winter growth lines.

Growth patterns. Growth functions were fitted to size-at-age data. To describe the growth of Strongylocentrotus droebachiensis collected at 50 to $60 \mathrm{~m}$ in Kobbefjord, we chose a flexible Richards' growth model (Richards 1959, Sugden et al. 1981), which has been shown to describe growth of this species particularly well (Blicher et al. 2007):

$$
D_{t}=D_{\infty}\left[1-(1-m) \exp \left\{\frac{-\left(t-t^{*}\right)}{T m^{m /(1-m)}}\right\}\right]^{1 /(1-m)}
$$

where $D_{\infty}$ is the asymptotic diameter $(\mathrm{mm}), t$ is individual age (yr), $t_{*}$ is an age-at-growth inflexion, $T$ (yr) is the time needed to grow from zero to $D_{\infty}$ at the maximum growth rate, and $m$ is a shape factor for Richards' curves. In the present study we also included an estimate of growth of $S$. droebachiensis collected at 5 to $15 \mathrm{~m}$ in Kobbefjord, which has been published in Blicher et al. (2007): $D_{t}=64.35[1+0.975 \exp (-0.185(t-$ 10.989)) $]^{-1.025}$. This was done to compare growth at different depths in Kobbefjord and to include this factor in the further analyses. 
Growth of Chlamys islandica was described by the specialized von Bertalanffy growth model:

$$
S H_{t}=S H_{\infty}\left(1-\mathrm{e}^{-K\left(t-t_{0}\right)}\right)
$$

where $S H_{t}$ is shell height (mm) at age $t(\mathrm{yr}), S H^{*}$ is the asymptotic shell height $(\mathrm{mm}), t_{0}$ is the age at which shell height would be zero and $K$ is a growth coefficient $\left(\mathrm{yr}^{-1}\right)$.

Production. We estimated the annual somatic production of average individuals, $\bar{P}_{\text {s(ind) }}$, in the 2 populations by the mass-specific growth rate method (Brey 2001). This method incorporates: (1) the size frequency of a population, (2) the growth function and (3) the size-mass relationship:

$$
\bar{P}_{\mathrm{s}(\text { ind })}=\sum_{i} F_{i} M_{\mathrm{s}, i} G_{i}
$$

where $F_{i}$ is the fraction of size class $i$ (2 mm intervals) in the population, $M_{\mathrm{s}, i}$ is the somatic mass ( $g$ AFDW) of an average individual in size class $i$, and $G_{i}$ is the mass-specific growth rate $\left(\mathrm{yr}^{-1}\right)$ of an average individual in size class i. $M_{\mathrm{s}, i} G_{i}$ equals the absolute individual somatic mass growth rate of an individual in size class $i, P_{\mathrm{s}(\mathrm{ind}), i}\left(\mathrm{~g} \mathrm{AFDW} \mathrm{yr}^{-1}\right.$ ). Thus, $\bar{P}_{\text {s(ind) }}$ is weighted by the frequency of different size classes in the populations. The expression of $G_{i}$ varies according to growth model used. For Strongylocentrotus droebachiensis in the present study the expression is:

$$
G_{i(S d)}=-\frac{b\left\{D_{i}-D_{i}^{m} D_{\infty}^{(1-m)}\right\}}{D_{i}(1-m) T m^{m /(1-m)}}
$$

where $b$ is the exponent of the size-mass relationship. $T, m$ and $D_{\infty}$ are parameters from the growth model (Eq. 3), and $D_{i}$ is the mean diameter of size class $i$. When using the specialized von Bertalanffy model, as in the case of Chlamys islandica in the present study, the expression of the weight-specific growth rate is:

$$
G_{i(C i)}=b K\left\{\left(S H_{\infty} / S H_{i}\right)-1\right\}
$$

where $b$ is the exponent of the size-mass relationship, $K$ and $S H_{\infty}$ are parameters from the growth model (Eq. 4), and $S H_{i}$ is the mean shell height in size class $i$.

Since both species involved in the present study have discrete reproductive cycles and spawn only once per year (Sundet \& Vahl 1981, Oganesyan 1998), we estimated the annual gonad production by monitoring the gonad mass of sea urchins and scallops in Kobbefjord in the spring, late summer and winter, i.e. in May and August 2007, and in February 2008. The reproductive output of an average individual of a population, $\bar{P}_{\mathrm{s}(\mathrm{ind})}$, was calculated on the basis of the difference between the observed minimum and maximum individual gonad mass in combination with the size frequency of the population:

$$
\bar{P}_{\text {g(ind })}=\sum_{i} F_{i} P_{\text {g(ind }), i}
$$

where $P_{g(\text { ind) }, i}$ is the reproductive output ( $g$ AFDW) of an average individual in size class $i$ estimated from gonad mass-at-size regressions.

At population level, the average annual somatic production, $P_{\mathrm{s}(\mathrm{pop})}$, and gonad production, $P_{\mathrm{g}(\mathrm{pop})}$, per square meter in each $10 \mathrm{~m}$ depth interval were calculated on the basis of Eqs. (5) \& (8) and the densities of the 2 species. In an attempt to extrapolate these calculations to fjord scale, a bathymetry model of Kobbefjord, based on multi-beam data from the Danish Navy Hydrographic Survey Group, was created using triangular interpolations of the data with a contouring and three-dimensional surface mapping program (Surfer 8). From this model, we estimated the seafloor area of the relevant depth intervals. By multiplying estimates of seafloor area with the average annual production in specific depth intervals, we estimated total production, $P_{\text {(tot) }}$, in the outer fjord region.

Carbon demand calculations. Organic carbon contents of bivalve tissue were determined on 6 replicate individuals. Samples were dried and homogenized and analysed on an elemental analyser (ANCA-GSL, SerCon). For Strongylocentrotus droebachiensis AFDW was converted to organic carbon (C) by the following factor (Blicher et al. 2007): $\mathrm{C}=0.5 \times A F D W$. Production-to-consumption ratios $(P: \mathrm{C})$ of marine invertebrates can vary considerably, and the number of published estimates are limited. For the 2 species involved in the present study, we used the following ratios: Strongylocentrotus droebachiensis: $P / C=0.1$ (Miller \& Mann 1973); Chlamys islandica: $P / C=0.075$ (Vahl 1981).

\section{RESULTS}

\section{Fjord bathymetry}

The available depth data for Kobbefjord allowed us to create a bathymetry model (Fig. 1b, data summarised in Tables 1 \& 2). Kobbefjord is a sill fjord, and the outer region (Fig. 1b) has an average depth of $\sim 44 \mathrm{~m}$, with a basin extending down to $\sim 120 \mathrm{~m}$ depth. The bathymetry model was used for the calculation of sea urchin and scallop production at a fjord scale.

\section{Densities and size frequencies}

As indicated by dredge collections, photographs of the seafloor revealed that Strongylocentrotus droebachiensis and Chlamys islandica clearly dominated the macrobenthic community $<60$ m depth (Fig. 2a,b). 
Table 1. Chlamys islandica. Mean $( \pm \mathrm{SE})$ somatic $\left(P_{\mathrm{s}}\right)$ and gonad $\left(P_{\mathrm{g}}\right)$ production on a population level in Kobbefjord. $P_{\mathrm{s}(\mathrm{pop})}$ and $P_{\mathrm{g}(\text { pop })}$ are the area-specific production values. $P_{\mathrm{s}(\mathrm{tot})}$ and $P_{\mathrm{g}(\mathrm{tot})}$ refer to the population production values in the given depth intervals. Total production was estimated at $40.5 \mathrm{t}$ ash-free dry weight (AFDW) $\mathrm{yr}^{-1}$

\begin{tabular}{|c|c|c|c|c|c|c|c|}
\hline Depth (m) & $\begin{array}{c}\text { Density } \\
\left(\text { Ind. } \mathrm{m}^{-2} \text { ) }\right.\end{array}$ & $\begin{array}{c}\text { Biomass } \\
(\mathrm{g} \mathrm{AFDW} \\
\left.\mathrm{m}^{-2}\right)\end{array}$ & $\begin{array}{c}P_{\mathrm{s}(\mathrm{pop})} \\
(\mathrm{g} \text { AFDW } \\
\mathrm{yr}^{-1} \mathrm{~m}^{-2} \text { ) }\end{array}$ & $\begin{array}{c}P_{\text {g(pop) }} \\
\text { (g AFDW } \\
\mathrm{yr}^{-1} \mathrm{~m}^{-2} \text { ) }\end{array}$ & $\begin{array}{c}\text { Area } \\
\left(\mathrm{m}^{2}\right)\end{array}$ & $\begin{array}{c}P_{\mathrm{s}(\mathrm{tot})} \\
\text { (g AFDW } \\
\mathrm{yr}^{-1} \text { ) }\end{array}$ & $\begin{array}{c}P_{\mathrm{g}(\text { tot })} \\
\text { (g AFDW } \\
\mathrm{yr}^{-1} \text { ) }\end{array}$ \\
\hline $0-10$ & 0 & 0 & 0 & 0 & 2712916 & 0 & 0 \\
\hline $10-20$ & 0 & 0 & 0 & 0 & 1752558 & 0 & 0 \\
\hline $20-30$ & $0.32(0.16)$ & $0.68(0.34)$ & $0.04(0.02)$ & $0.11(0.05)$ & 1414558 & 55835 & 149065 \\
\hline $30-40$ & $5.03(0.90)$ & $10.58(1.89)$ & $0.61(0.11)$ & $1.64(0.29)$ & 1544902 & 949088 & 2533824 \\
\hline $40-50$ & $24.45(2.34)$ & $51.40(4.91)$ & $2.98(0.29)$ & $7.97(0.76)$ & 1906172 & 5689642 & 15189900 \\
\hline $50-60$ & $16.46(2.03)$ & $34.61(4.28)$ & $2.01(0.25)$ & $5.36(0.66)$ & 1940695 & 3900709 & 10413902 \\
\hline $60-70$ & $1.36(0.28)$ & $2.87(0.59)$ & $0.17(0.03)$ & $0.44(0.09)$ & 2151090 & 358305 & 956584 \\
\hline $70-80$ & $0.79(0.27)$ & $1.66(0.57)$ & $0.10(0.03)$ & $0.26(0.09)$ & 805514 & 77739 & 207544 \\
\hline $80-90$ & 0 & 0 & 0 & 0 & 653348 & 0 & 0 \\
\hline $90-100$ & 0 & 0 & 0 & 0 & 506591 & 0 & 0 \\
\hline $100-110$ & 0 & 0 & 0 & 0 & 737266 & 0 & 0 \\
\hline $110-120$ & 0 & 0 & 0 & 0 & 149232 & 0 & 0 \\
\hline Sum & & & & & 16275214 & 11031319 & 29450819 \\
\hline
\end{tabular}

Table 2. Strongylocentrotus droebachiensis. Mean $( \pm \mathrm{SE})$ somatic $\left(P_{\mathrm{s}}\right)$ and gonad $\left(P_{\mathrm{g}}\right)$ production on a population level in Kobbefjord. $P_{\mathrm{s}(\mathrm{pop})}$ and $P_{\mathrm{g}(\text { pop })}$ are the area-specific production values. $P_{\mathrm{s}(\mathrm{tot})}$ and $P_{\mathrm{g}(\mathrm{tot})}$ refer to the population production values in the given depth intervals. Total production was estimated at $52 \mathrm{t} \mathrm{AFDW} \mathrm{yr}^{-1}$

\begin{tabular}{|c|c|c|c|c|c|c|c|}
\hline Depth (m) & $\begin{array}{l}\text { Density } \\
\left(\text { Ind. } \mathrm{m}^{-2} \text { ) }\right.\end{array}$ & $\begin{array}{c}\text { Biomass } \\
(\mathrm{g} \mathrm{AFDW} \\
\left.\mathrm{m}^{-2}\right)\end{array}$ & $\begin{array}{c}P_{\mathrm{s}(\text { pop })} \\
(\mathrm{g} \mathrm{AFDW} \\
\mathrm{yr}^{-1} \mathrm{~m}^{-2} \text { ) }\end{array}$ & $\begin{array}{c}P_{\text {g(pop) }} \\
\text { (g AFDW } \\
\mathrm{yr}^{-1} \mathrm{~m}^{-2} \text { ) }\end{array}$ & $\begin{array}{c}\text { Area } \\
\left(\mathrm{m}^{2}\right)\end{array}$ & $\begin{array}{c}P_{\mathrm{s}(\mathrm{tot})} \\
\text { (g AFDW } \\
\mathrm{yr}^{-1} \text { ) }\end{array}$ & $\begin{array}{c}P_{\mathrm{g}(\text { tot })} \\
\text { (g AFDW } \\
\left.\mathrm{yr}^{-1}\right)\end{array}$ \\
\hline $0-10$ & $15.41(1.30)$ & $26.41(2.24)$ & $3.76(0.32)$ & $6.01(0.51)$ & 2712916 & 10202014 & 16305025 \\
\hline $10-20$ & $13.40(1.85)$ & $22.97(3.17)$ & $3.27(0.45)$ & $5.23(0.72)$ & 1752558 & 5732521 & 9161809 \\
\hline $20-30$ & $4.04(1.12)$ & $6.93(1.92)$ & $0.99(0.27)$ & $1.58(0.44)$ & 1414558 & 1395816 & 2230816 \\
\hline $30-40$ & $1.69(0.38)$ & $2.89(0.66)$ & $0.25(0.06)$ & $0.66(0.15)$ & 1544902 & 382719 & 1015749 \\
\hline $40-50$ & $3.37(0.65)$ & $5.78(1.11)$ & $0.50(0.10)$ & $1.32(0.25)$ & 1906172 & 944721 & 2507323 \\
\hline $50-60$ & $1.40(0.38)$ & $2.40(0.66)$ & $0.21(0.06)$ & $0.55(0.15)$ & 1940695 & 399442 & 1060132 \\
\hline $60-70$ & $0.60(0.24)$ & $1.02(0.42)$ & $0.09(0.04)$ & $0.23(0.12)$ & 2151090 & 188621 & 500607 \\
\hline $70-80$ & 0 & 0 & 0 & 0 & 805514 & 0 & 0 \\
\hline $80-90$ & 0 & 0 & 0 & 0 & 653348 & 0 & 0 \\
\hline $90-100$ & 0 & 0 & 0 & 0 & 506591 & 0 & 0 \\
\hline $100-110$ & 0 & 0 & 0 & 0 & 737266 & 0 & 0 \\
\hline $110-120$ & 0 & 0 & 0 & 0 & 149232 & 0 & 0 \\
\hline Sum & & & & & 16275214 & 19245855 & 32781462 \\
\hline
\end{tabular}

The images also showed that stones, rock, sand and shell gravel were the most abundant substrates at this depth interval and that soft sediment was not typical. The remaining macrobenthic community in this zone consisted primarily of epifaunal taxa such as barnacles, chitons, holothurians, sponges, bryozoans and ascidians $(<10 \% \mathrm{WW})$, but also the bivalves Clinocardium sp., Hiatella sp. and Astarte spp. were caught sporadically when dredging (data not shown). The density of sea urchins and scallops decreased to zero in concurrence with a gradual change in structure of the sea bed from gravel and stones to soft mud from a depth of $\sim 60$ $\mathrm{m}$ down to $\sim 120 \mathrm{~m}$. Even though the epifaunal biomass clearly decreased at $>60 \mathrm{~m}$, burrows and surface tracks on the sediment surface still indicated macrofaunal activity (Fig. 2c). S. droebachiensis and C. islandica were, to a large extent, vertically separated in Kobbefjord. The density of sea urchins was highest at $<20 \mathrm{~m}$ depth (ranging from 2 to 38 ind. $\mathrm{m}^{-2}$ ), and scallop densities peaked between 30 and $60 \mathrm{~m}$ depth (ranging from 0 to 57 ind. $\mathrm{m}^{-2}$ ). The weighted mean densities (with respect to sea floor area) across all depths were 4.9 ind. $\mathrm{m}^{-2}(\mathrm{n}=288, \mathrm{SE}=0.40)$ and 5.6 ind. $\mathrm{m}^{-2}(\mathrm{n}=$ 288, $\mathrm{SE}=0.57$ ) for $S$. droebachiensis and C. islandica, respectively (Fig. 3). Mean biomass of S. droebachiensis and C. islandica at 0 to $120 \mathrm{~m}$ was estimated at 20.5 g AFDW m ${ }^{-2}\left(\sim 29 \mathrm{~g} \mathrm{AFDW} \mathrm{m}^{-2}\right.$ at 0 to $\left.60 \mathrm{~m}\right)$, ranging from a minimum of zero at $>80 \mathrm{~m}$ depth to a maximum 

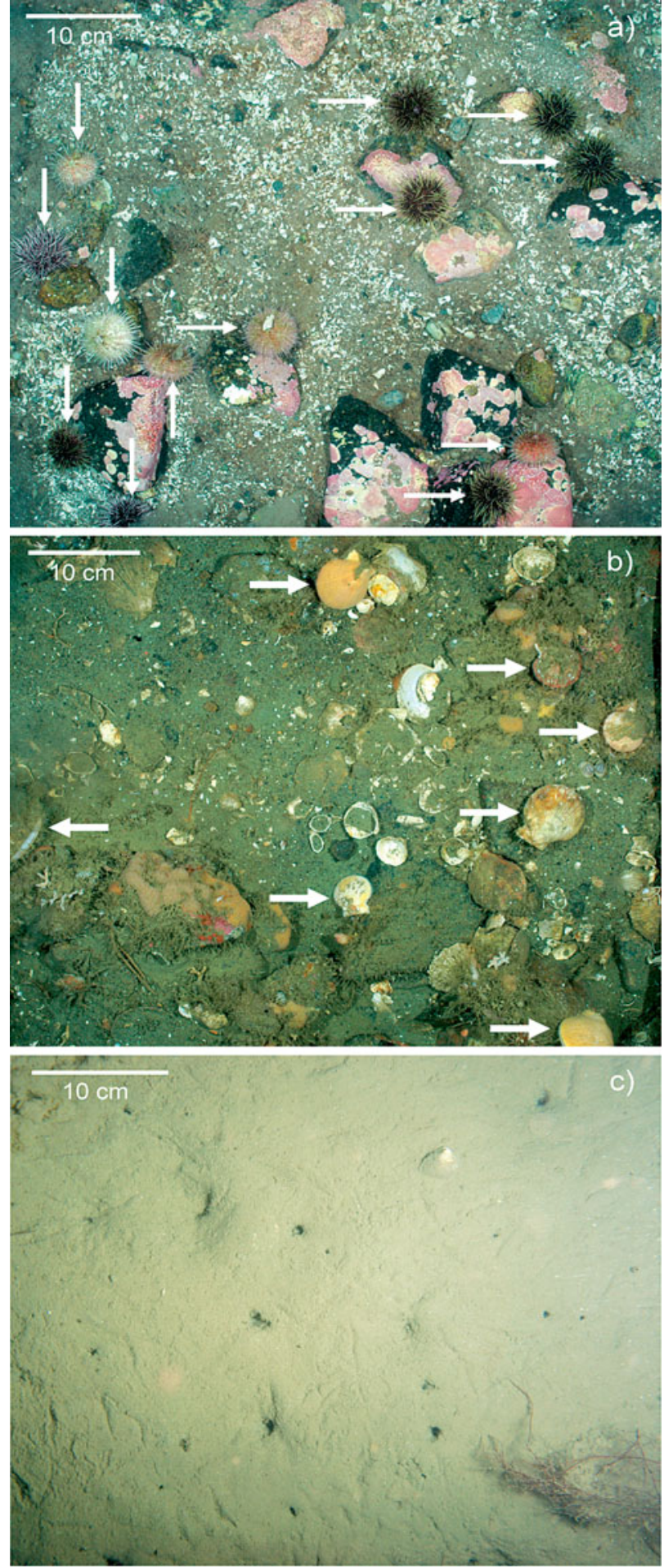

Fig. 2. Underwater photographs of the seafloor at different depths in Kobbefjord. (a) The 10 to 20 m stratum. Dominance of Strongylocentrotus droebachiensis indicated by white arrows. (b) The 50 to $60 \mathrm{~m}$ stratum. Dominance of Chlamys islandica indicated by white arrows. (c) The 80 to $90 \mathrm{~m}$ stratum. Soft sediment with burrows and surface tracks. Each photo can be regarded as representative of the given depth interval with respect to characteristic macrofaunal and seafloor structure of $57.2 \mathrm{~g} \mathrm{AFDW} \mathrm{m}^{-2}$ at 40 to $50 \mathrm{~m}$ depth (Tables 1 \& 2). The size frequencies, which resulted from a number of dredge collections at 5 to $15 \mathrm{~m}$ and 50 to $60 \mathrm{~m}$ depths through 2007 and 2008, are illustrated in Fig. 4. The size structure of $S$. droebachiensis was unimodal and dominated by individuals between 40 and $60 \mathrm{~mm}$ in diameter. The population of $C$. islandica also had a relatively high frequency of large specimens (55 to $75 \mathrm{~mm}$ ), but not as distinctly so as sea urchins.

\section{Growth patterns}

Growth functions were fitted to size-at-age data for both species collected at 50 to $60 \mathrm{~m}$ depth in the outer Kobbefjord (Fig. 5): Strongylocentrotus droebachiensis: $D_{t}=69.64[1+0.005 \exp (-0.146(t-5.558))]^{-200.275}$ $\left(\mathrm{n}=73, \mathrm{R}^{2}=0.928\right) ;$ Chlamys islandica: $S H_{t}=$ $79.54[1-\exp (-0.139(t-0.916))]\left(\mathrm{n}=80, \mathrm{R}^{2}=0.927\right)$.

The size-at-age data and growth curve for sea urchins collected at shallower depths (5 to $15 \mathrm{~m}$ ) in Kobbefjord (Blicher et al. 2007) are also illustrated in Fig. 5.

\section{Individual biomass and production}

For a sub-sample of Chlamys islandica collected in Kobbefjord in May and August 2007 and February 2008 a relation between somatic mass, $M_{\mathrm{s}}$ (g AFDW), and shell height, $S H(\mathrm{~mm})$, was established ( $\mathrm{SH}$ ranging from 19.8 to $86.3 \mathrm{~mm}$ ): $M_{\mathrm{s}}=7.328 \times 10^{-6} S H^{2.988}(\mathrm{n}=$ $\left.134, \mathrm{R}^{2}=0.96\right)$.

For Strongylocentrotus droebachiensis we pooled the size-mass data for sea urchins from 7 different

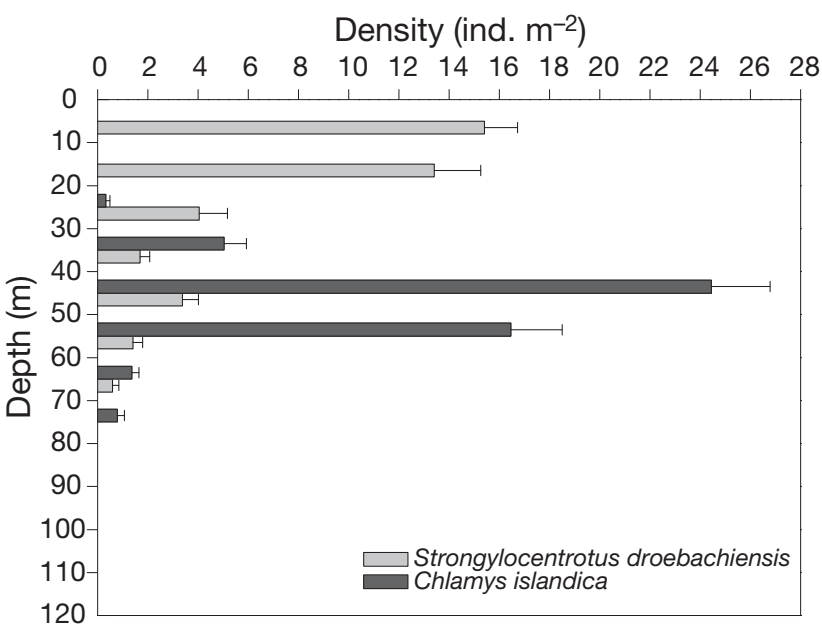

Fig. 3. Chlamys islandica, Strongylocentrotus droebachiensis. Average densities (ind. $\mathrm{m}^{-2}$ ) and standard error in $10 \mathrm{~m}$ depth intervals in Kobbefjord 

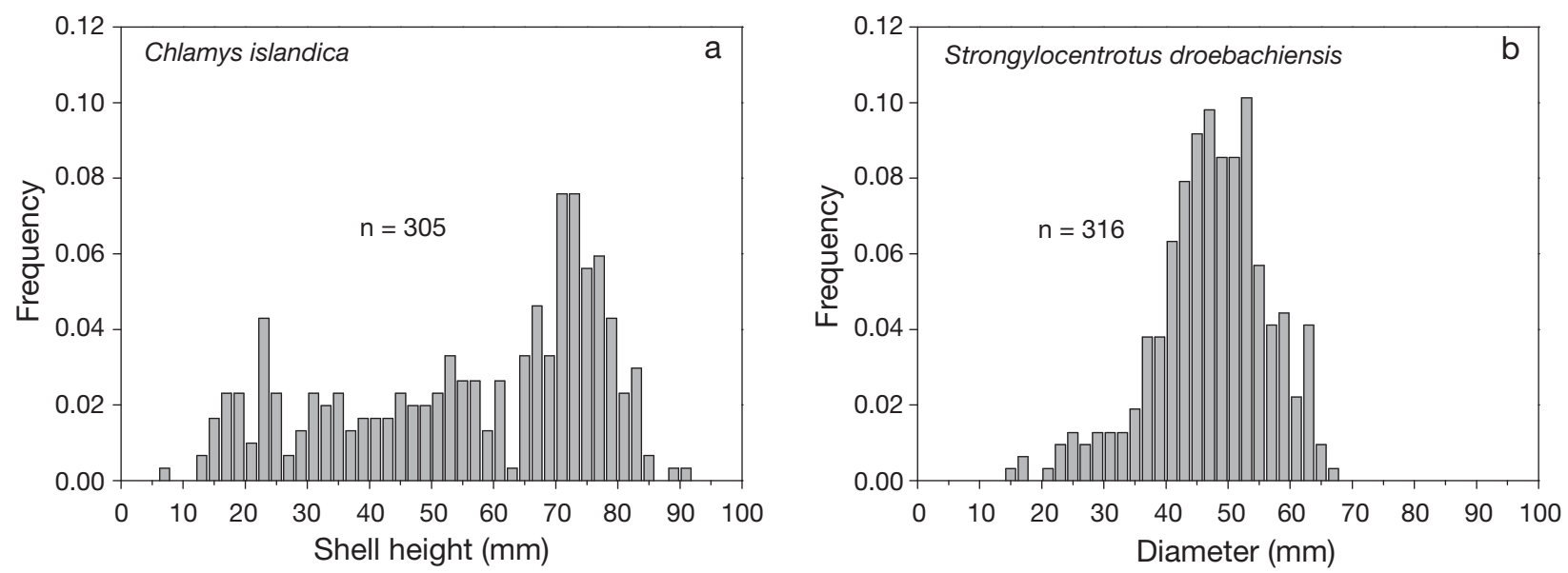

Fig. 4. (a) Chlamys islandica and (b) Strongylocentrotus droebachiensis size frequencies collected in 2007 and 2008 in Kobbefjord
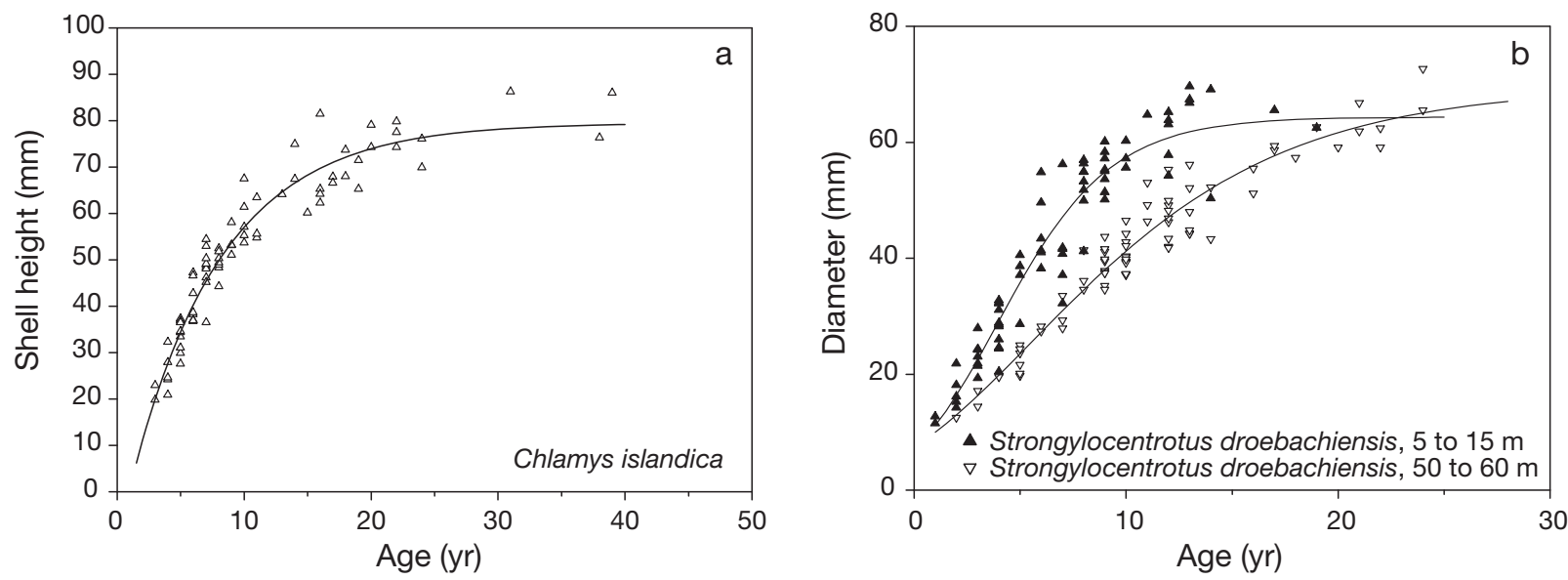

Fig. 5. Chlamys islandica, Strongylocentrotus droebachiensis. Growth curves fitted to size-at-age data for specimens collected in Kobbefjord. (a) $C$. islandica $S H_{t}=79.54[1-\exp (-0.139(t-0.916))]$. (b) $S$. droebachiensis at 5 to $15 \mathrm{~m}: D t=64.35[1+$ $0.975 \exp (-0.185(t-10.989))]^{-1.025} ;$ and at 50 to $60 \mathrm{~m}: D t=69.64[1+0.005 \exp (-0.146(t-5.558))]^{-200.275}$

Greenland populations (Blicher et al. 2007) to establish a relation between somatic mass, $M_{\mathrm{s}}$ (g AFDW), and diameter, $D(\mathrm{~mm})$, which can be considered to be general for this species: $M_{\mathrm{s}}=3.434 \times 10^{-5} D^{2.690}(\mathrm{n}=213$, $\left.\mathrm{R}^{2}=0.95\right)$.

For both species we observed minimum gonad mass in August and maximum in May (Fig. 6). Depth had no effect on the gonad mass of Strongylocentrotus droebachiensis at any of the sampling dates, which we tested by comparing gonad indices, $G I_{S d}=$ gonad DW/total WW (Students' $t$-test, 2-tailed, p > 0.05). Consequently, the data from the 2 sampling depths were pooled.

Based on size-mass relations and growth models for the 2 species, the annual individual somatic production, $P_{\mathrm{s}(\text { ind) }}$, as a function of size was calculated (Fig. 7). For Chlamys islandica $P_{\text {s(ind) }}$ peaked at $0.22 \mathrm{~g} \mathrm{AFDW}$ ind..$^{-1} \mathrm{yr}^{-1}$ at a shell height of $\sim 55 \mathrm{~mm}$. Maximum $P_{\mathrm{s}(\mathrm{ind})}$ for Strongylocentrotus droebachien- sis was found at a diameter of $\sim 45 \mathrm{~mm}$, but differed slightly between depths. For specimens collected at 5 to 15 and 50 to $60 \mathrm{~m}, P_{\text {s(ind) }}$ peaked at 0.30 and $0.17 \mathrm{~g}$ AFDW ind. ${ }^{-1} \mathrm{yr}^{-1}$, respectively. The observed seasonal variations in gonad status were used to establish relations between size and reproductive output for $C$. islandica and $S$. droebachiensis as illustrated in Fig. 7. We considered the size frequencies (Fig. 4) to be representative for the 2 populations and estimated the average somatic production at $0.122 \mathrm{~g} \mathrm{AFDW}$ ind. ${ }^{-1} \mathrm{yr}^{-1}$ for C. islandica and 0.243 and $0.147 \mathrm{~g}$ AFDW ind. ${ }^{-1} \mathrm{yr}^{-1}$ for $S$. droebachiensis at 5 to 15 and 50 to $60 \mathrm{~m}$ depth, respectively. Average individual gonad production was $0.326 \mathrm{~g}$ AFDW ind. ${ }^{-1} \mathrm{yr}^{-1}$ for $C$. islandica and $0.390 \mathrm{~g}$ AFDW ind. ${ }^{-1}$ $\mathrm{yr}^{-1}$ for $S$. droebachiensis. In conclusion, reproduction represents a major part of the total annual production (62 to $73 \%$ ) for the species involved in the present study. 

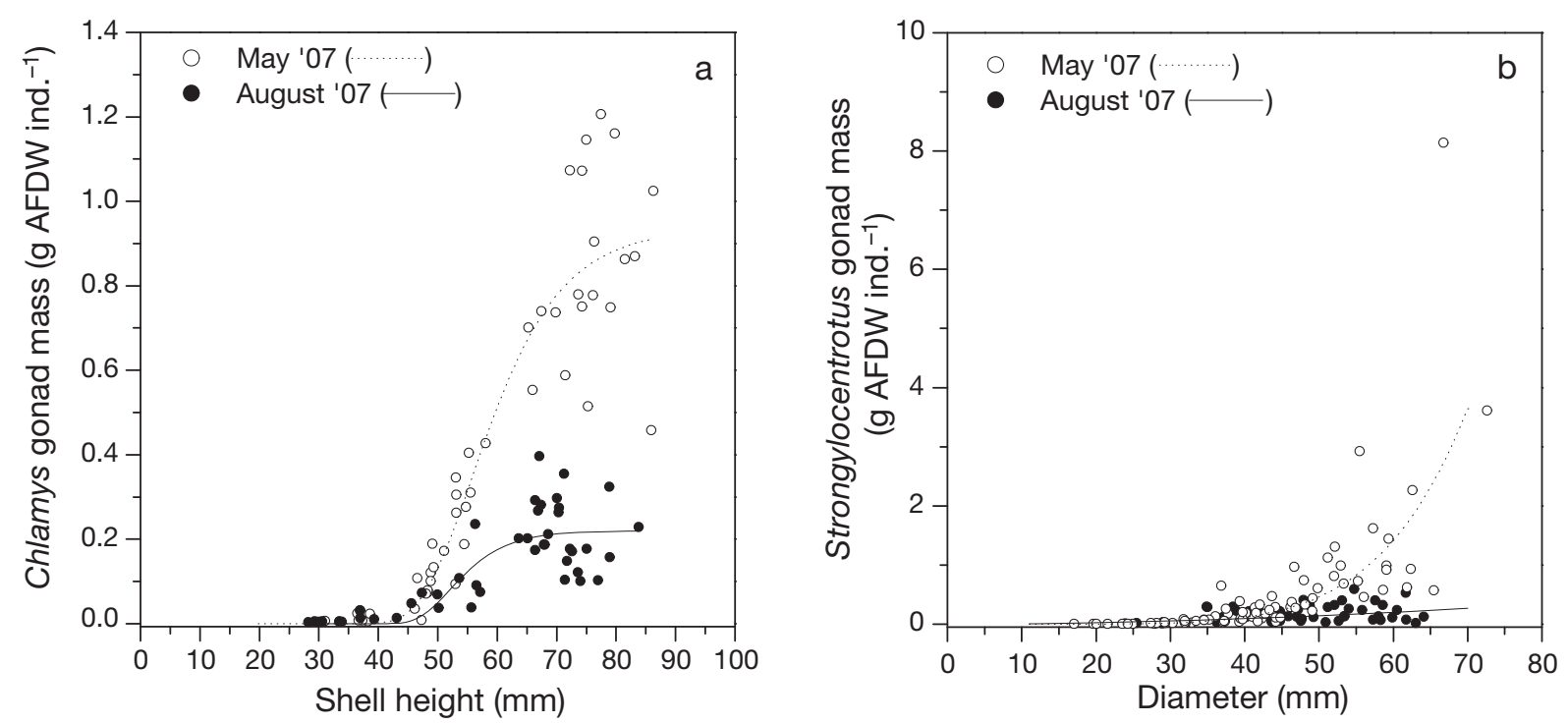

Fig. 6. Chlamys islandica, Strongylocentrotus droebachiensis. May and August were considered to be the periods of maximum and minimum gonad mass, respectively, for both species. (a) The Gompertz function was fitted to gonad mass-at-size data for $C$. islandica: $M_{\mathrm{g}(\mathrm{Ci})}^{\mathrm{May}}=0.936 \mathrm{e}^{-\exp [-0.118(\mathrm{SH} t-55.740)]}\left(\mathrm{n}=60, \mathrm{R}^{2}=0.87\right)$ and $M_{\mathrm{g}(\mathrm{Ci})}^{\mathrm{Aug}} 0.220 \mathrm{e}^{-\exp [-0.118(S H t-52.090)]}\left(\mathrm{n}=44, \mathrm{R}^{2}=0.63\right)$. (b) A power function was used for $S$. droebachiensis: $M_{\mathrm{g}(S d)}^{\mathrm{May}} 1.631 \times 10^{-11} D_{t}^{6.151}\left(\mathrm{n}=82, \mathrm{R}^{2}=0.85\right)$ and $M_{\mathrm{g}(S d)}^{\mathrm{Aug}} 8.753 \times 10^{-5} D_{t}^{1.888}\left(\mathrm{n}=53, \mathrm{R}^{2}=0.17\right)$
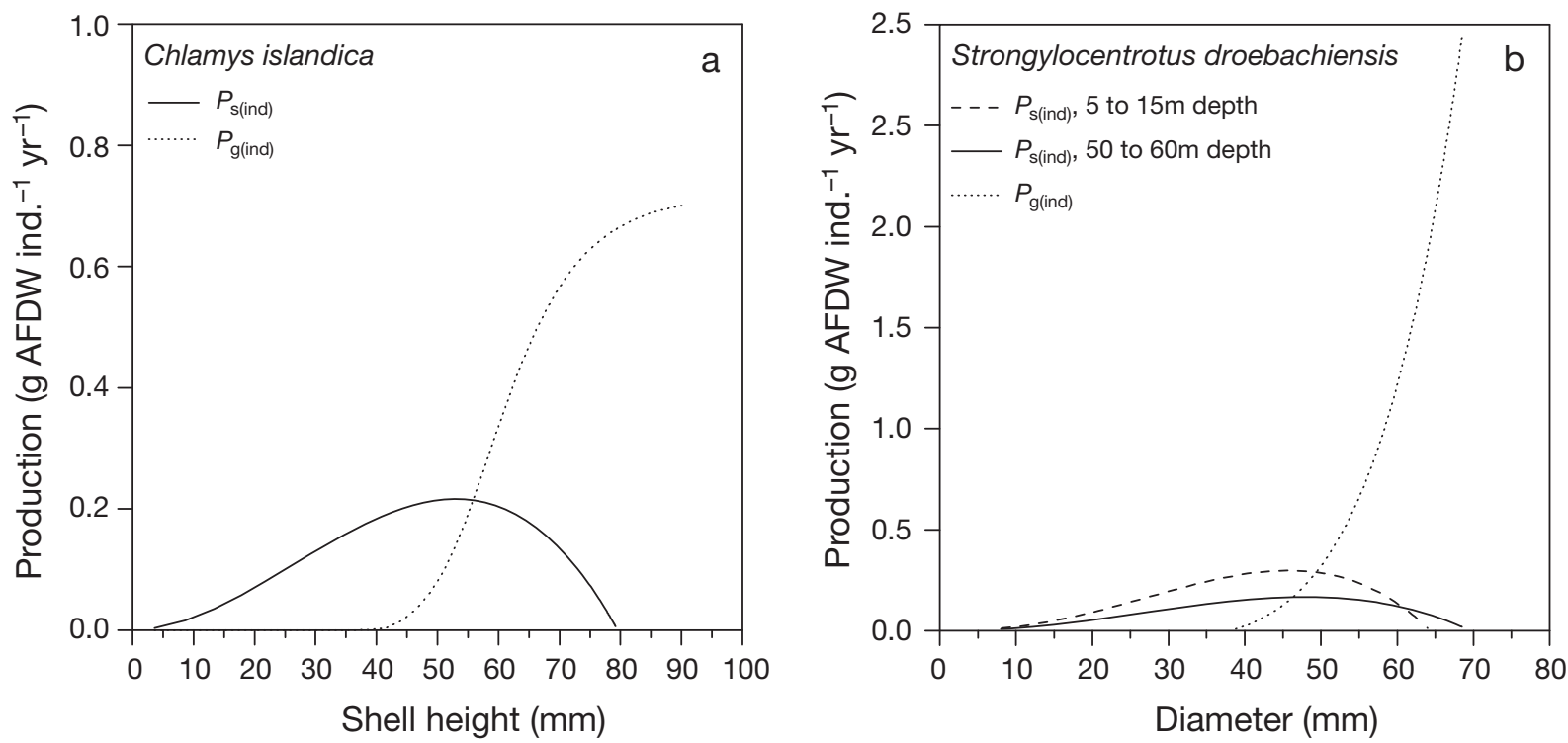

Fig. 7. Annual individual somatic production, $P_{\mathrm{s}(\mathrm{ind})}$, and gonad output, $P_{\mathrm{g}(\mathrm{ind})}(\mathrm{g}$ AFDW) in relation to size of: (a) Chlamys islandica and (b) Strongylocentrotus droebachiensisin Kobbefjord

\section{Population production and carbon demand}

The species densities illustrated in Fig. 3 were considered to be representative of the outer region of Kobbefjord (defined in Fig. 1b), and these data were used to estimate the biomass and production of the 2 populations. The individual production rates for Strongylocentrotus droebachiensis collected at 5 to $15 \mathrm{~m}$ and 50 to $60 \mathrm{~m}$ depth were considered valid in the depth intervals from 0 to $30 \mathrm{~m}$ and from 30 to $70 \mathrm{~m}$, respectively. Tables $1 \& 2$ summarise the calculation of the depth-specific population production, $P_{(\mathrm{pop})}$, of Chlamys islandica and $S$. droebachiensis, and total production, $P_{(\text {tot })}$, in which the bathymetry of Kobbefjord is considered. For sea urchins, $P_{\text {(pop) }}$ peaked at 0 to $10 \mathrm{~m}$ depth at a value of $9.77 \mathrm{~g}$ AFDW $\mathrm{m}^{-2} \mathrm{yr}^{-1}$, while scallop production was highest at 
40 to $50 \mathrm{~m}$ depth and reached a value of $10.95 \mathrm{~g}$ AFDW $\mathrm{m}^{-2} \mathrm{yr}^{-1}$. Averaged over the outer region of Kobbefjord, these values were 3.20 and $2.49 \mathrm{~g} \mathrm{AFDW} \mathrm{m}^{-2} \mathrm{yr}^{-1}$ for sea urchins and scallops, respectively. The productionto-biomass ratios were 0.31 and 0.37 for the shallow- and deep-living sea urchins, respectively, and 0.21 for scallops. Total annual production of $C$. islandica and $S$. droebachiensis was estimated at $92.5 \mathrm{t}$ AFDW in the outer region of Kobbefjord.

The average organic carbon content of scallop tissue was measured at $0.44 \times \mathrm{AFDW}(\mathrm{n}=6, \mathrm{SE}=0.01)$, which was used for the estimation of carbon demand. Using previously published estimates of production-to-consumption ratios (see 'Materials and methods'), the mean annual carbon demands for Strongylocentrotus droebachiensis and Chlamys islandica in outer Kobbefjord $\left(\sim 16 \mathrm{~km}^{2}\right)$ amounted to 16.0 and $14.6 \mathrm{~g} \mathrm{C} \mathrm{m}^{-2}$, respectively, or $\sim 260$ t $\mathrm{C}$ for sea urchins and $\sim 237 \mathrm{t} \mathrm{C}$ for scallops.

\section{DISCUSSION}

\section{Abundance of Strongylocentrotus droebachiensis and Chlamys islandica}

Photographs of the seafloor confirmed that $S$. droebachiensis and C. islandica were very abundant in Kobbefjord and that these 2 species clearly dominated the macrobenthic community at depths of $<60 \mathrm{~m}$, where the seabed primarily consisted of stones, rock, sand and shell gravel. The density of $S$. droebachiensis in Kobbefjord was high but not extreme in comparison to other observations in coastal areas of the North Atlantic (Himmelman et al. 1983, Hop et al. 2002, Gagnon et al. 2004). S. droebachiensis has been observed in high densities in many areas along the Greenland coast, but never in high numbers at $>40 \mathrm{~m}$ depth, which agrees with our observations in Kobbefjord (Nielsen 1994). C. islandica was only found at $>20 \mathrm{~m}$ depth. At these depths, densities were moderate compared to mean densities of 50 to 70 ind. $\mathrm{m}^{-2}$ in a scallop bed in northern Norway, but in the range of observations off Svalbard (Vahl 1981, Rubach \& Sundet 1987). The depth distribution of $C$. islandica in Kobbefjord fit well with the general trend of peak abundance between 20 and $60 \mathrm{~m}$ depth observed off the West Greenland coast (Pedersen 1994). Both C. islandica and $S$. droebachiensis have been registered in numerous areas in fjords and along the Greenland coast and most often in gravelly or rocky habitats (Nielsen 1994, Pedersen 1994), as observed in Kobbefjord. Thus, the degree of dominance of these 2 species is probably not unique for the study area, but is dependent on habitat structure and hydrographic conditions.
Although it is still uncertain which parameters are responsible for the distribution patterns and indeed also the vertical separation of the 2 species, it is expected that dominance by $C$. islandica and $S$. droebachiensis of macrobenthic communities is common in many coastal areas of West Greenland. The average densities in Kobbefjord are based on underwater photographs covering a total of $141 \mathrm{~m}^{2}$ in this relatively small fjord. This area is large compared to that in similar studies using other methods for quantification of benthos (e.g. cayak corer, van veen grab, box corer). Moreover, the underwater images revealed clear depth-related patterns in the distribution of the 2 species. With the given growth patterns and age structures of the 2 populations, we do not expect either densities or size frequencies to vary considerably on a short-term scale. Thus, we find it reasonable to assume that the average densities can be regarded as representative for the outer fjord region.

\section{Individual production}

\section{Somatic growth}

In Kobbefjord, growth patterns of Strongylocentrotus droebachiensis differed between depths. Maximum $P_{\mathrm{s} \text { (ind), }}$ which can be regarded as an expression of growth performance (Brey 2001) was $~ 40 \%$ lower for the deeper living (50 to $60 \mathrm{~m}$ ) sea urchins compared to those living at depths of 5 to $15 \mathrm{~m}$. Overall, growth of $S$. droebachiensis in Kobbefjord was slower than in temperate areas, but faster than in high-Arctic populations. The individual growth performances differed by a factor of 2 to 3 between Kobbefjord and the highArctic sites of Young Sound and Qaanaaq (Blicher et al. 2007, and references therein). Chlamys islandica collected at 50 to $60 \mathrm{~m}$ depth in Kobbefjord reached a shell height of $60 \mathrm{~mm}$ at an age of $11 \mathrm{yr}$, compared to 9-10 yr for Svalbard and other West Greenland populations. Populations in northern Norway, Canada and Iceland reached $60 \mathrm{~mm}$ shell height in 6 to $7 \mathrm{yr}$ (Pedersen 1994 and references therein), and the population in Kobbefjord can thus be regarded as rather slow growing compared to other North Atlantic populations. Hence, we can consider 2 types of growth variation: (1) local variation, e.g. the depth-related differences in growth of sea urchins reported in the present study and (2) growth variation observed between regions. It is well documented that growth of both $S$. droebachiensis and C. islandica is highly affected by food quantity and quality (Wallace \& Reinsnes 1985, Meidel \& Scheibling 1999), which differ greatly on local, regional, as well as temporal scales. But temperature itself acting on physiological processes can also influ- 
ence the potential of growth in ectotherms (e.g. Pörtner et al. 2005). During spring and summer, from May to September, when we expect the highest growth rates, the average temperatures at 5 and $50 \mathrm{~m}$ depth in the entrance to Kobbefjord were 3.8 and $1.9^{\circ} \mathrm{C}$, respectively, in 2008 , i.e. they reflected a difference of $1.9^{\circ} \mathrm{C}$ (M. E. Blicher unpubl. data). Obviously, temperature regimes also differ on a regional scale in the Arctic. For comparison, the average temperature in the high-Arctic fjord Young Sound is $\sim 2^{\circ} \mathrm{C}$ at $5 \mathrm{~m}$ depth and $-1.5^{\circ} \mathrm{C}$ at $50 \mathrm{~m}$ depth in the productive summer period (Rysgaard et al. 1999). Thus, the regional difference in temperature between the sub-Arctic and highArctic is within 2 to $4^{\circ} \mathrm{C}$, depending on depth and season. Pectinids, as well as echinoids, have been subject to investigations concerning the effect of temperature on individual growth and metabolism. Studies of polar species generally agree that temperature alone cannot explain either the temporal or spatial variation in metabolism or growth (e.g. Vahl 1978, Brockington \& Clarke 2001, Heilmayer et al. 2004, Sejr et al. 2004). These results in combination suggest that the difference in temperature regime between sub-Arctic and high-Arctic areas, and between different depths, may be of secondary importance for marine macrobenthic production. It seems more likely that the geographical variation in primary production, which can differ by a factor of 10 to 20 as in the case of Kobbefjord and Young Sound, affects food availability for secondary producers and to a large extent is responsible for regional differences in the growth of sea urchins, which has previously been reported (Blicher et al. 2007). Hence, the depth-related growth variation of $S$. droebachiensis reported in the present study is most likely related to differences in food quantity and quality, in this case, between the shallow photic zone (potential food: macroalgae, benthic microalgae and pelagic phytoplankton) and the aphotic zone (sedimentary phytoplankton and detritus, encrusting algae and drifting macroalgae), more than to differences in temperature. Growth of C. islandica in Kobbefjord was not compared across depths, but depth has been shown to affect the growth of this species due to its effect on food availability (Wallace \& Reinsnes 1985) and other studies indicate local growth variations (Engelstoft 2000). Thus, the relatively slow growth of C. islandica reported here compared to the results of other West Greenland and North Atlantic studies may be a consequence of sampling depth and other local conditions as of regional differences as well.

In conclusion, the primary reasons for variations in the individual growth patterns of Chlamys islandica and Strongylocentrotus droebachiensis presumably lie in variations in the food availability on both local and regional scales.
Reproduction

High allocation of resources to reproductive tissue was characteristic of both Chlamys islandica and Strongylocentrotus droebachiensis, and reproduction accounted for more than half of total annual production. These results agree with other estimates indicating that polar macrobenthic populations might invest more energy in reproduction, relative to somatic growth, than populations from warmer climates (Brey et al. 1995, Blicher et al. 2007). This may either be an adaptation to life in the polar environment (e.g. low temperature, low food supply, low recruitment success), or a consequence of the age and size structure, which could be right-skewed in undisturbed and, often, slow-growing polar populations (e.g. Sejr et al. 2002, Heilmayer et al. 2003), and thus indirectly related to the polar environment. Regardless of the ecological reasons for the tendency towards high reproductive output relative to somatic production in some polar macrobenthic populations, our results highlight the importance of including reproduction in estimates of population production in any study concerned with ecosystem carbon flow.

\section{Role of macrobenthos in Kobbefjord carbon cycling}

The estimate of an annual carbon demand of $\sim 498 \mathrm{t}$ C for Chlamys islandica and Strongylocentrotus droebachiensis, which almost exclusively originated from $<60 \mathrm{~m}$ depth, corresponds to $30.6 \mathrm{~g} \mathrm{C} \mathrm{m}^{-2} \mathrm{yr}^{-1}$ (ranging from 0 to $73 \mathrm{~g} \mathrm{C} \mathrm{m}^{-2} \mathrm{yr}^{-1}$ depending on depth) averaged across the entire outer fjord sea floor area $\left(\sim 16 \mathrm{~km}^{2}\right)$, or 21 to $45 \%$ of total pelagic primary production in the entire outer fjord region. The role of macroalgae and benthic microalgae as food for sea urchins might be considerable at the shallowest depths. Unfortunately, we do not know the amount of organic carbon produced by benthic primary producers, and thus we cannot include this in our comparison for the time being. No estimates of advection and inputs from land are available either. Still, we believe that the level of pelagic primary production generally gives an indication of the overall productivity and food availability in shallow systems.

Keeping in mind that our estimate of the macrobenthic carbon demand includes only 2 species, albeit the dominant ones, and that our knowledge of several potentially important contributors to the carbon source of the macrobenthic community is limited, it is evident that a complete quantification of the role of macrobenthic organisms in the Kobbefjord carbon cycling is difficult. However, it was evident from the sea floor photographs of the soft bottom at $>60 \mathrm{~m}$ that infaunal 
activity may be considerable (Fig. 2c). In an attempt to roughly estimate the infaunal activity at these depths, we supplemented our estimate with the results from oxygen incubations of sediment cores $\left(22 \mathrm{~cm}^{2}\right.$ each) sampled at a single station in the deepest part of Kobbefjord (Mikkelsen et al. 2008b). The difference between the total oxygen uptake and the diffusive oxygen uptake, which we considered as an approximate estimate of infaunal activity (excluding the largest fauna), was converted to an average carbon demand of $7.7 \mathrm{~g} \mathrm{C} \mathrm{m}^{-2} \mathrm{yr}^{-1}$ (seasonally varying from 16.8 to $25.2 \mathrm{mg} \mathrm{C} \mathrm{m}^{-2} \mathrm{~d}^{-1}$ ), assuming a respiratory quotient of 0.8 (Hatcher 1989). Extrapolated to the seafloor area between 60 and $120 \mathrm{~m}$ depth, where soft sediment dominates, this amounts to an annual carbon demand of $39 \mathrm{t} \mathrm{C}$ or $2.4 \mathrm{~g} \mathrm{C} \mathrm{m}^{-2}$ averaged across the entire outer fjord region. Combined with the estimate for Chlamys islandica and Strongylocentrotus droebachiensis, the macrobenthic carbon demand in Kobbefjord adds up to $33 \mathrm{~g} \mathrm{C} \mathrm{m}^{-2} \mathrm{yr}^{-1}$. This estimate gives some important indications of a macrobenthic community that requires a considerable amount of carbon compared to the pelagic primary production of 75 to $160 \mathrm{~g} \mathrm{C} \mathrm{yr}^{-1}$ of the specific area. The proportion of the consumed organic matter that is excreted as either dissolved organic matter or faeces is in the range of 60 to $80 \%$ for C. islandica and S. droebachiensis (Miller \& Mann 1973, Vahl 1981). This contribution of fractionated organic matter to the benthic environment may indeed stimulate bacterial mineralisation (Mamelona \& Pelletier 2005). In addition, the high reproductive outputs show that large amounts of eggs are released into the water column. However, we cannot even guess at the proportion of eggs that survive and develop into actively feeding planktonic larvae, or at how many may reach metamorphosis. In any case, spawning seems to represent a potentially important coupling between the benthic and pelagic communities.

Given the dominance and high production of Chlamys islandica and Strongylocentrotus droebachiensis in the shallow ( $<60 \mathrm{~m}$ ) and presumably most productive areas of Kobbefjord, it is reasonable to conclude that the 2 species in the present study, and the macrobenthic community as such, play an essential role in the carbon cycling of the fjord, and that a large fraction of the total macrobenthic carbon demand is included in our combined estimate. However, there are several basically unstudied parameters in the Kobbefjord ecosystem, such as pelagic secondary production, benthic primary production, sedimentation and bacterial mineralisation. These obvious gaps in our knowledge make it difficult to draw any conclusions on the exact routes of carbon through the Kobbefjord ecosystem.

\section{Comparison of macrobenthic activities in the Arctic}

Production of Strongylocentrotus droebachiensis in Kobbefjord was high compared to another estimate from the Arctic. The sea urchin population in Kobbefjord produced 15 times more biomass (AFDW m ${ }^{-2} \mathrm{yr}^{-1}$ ) than $S$. droebachiensis in the high-Arctic fjord Young Sound in a comparable depth range (0 to $60 \mathrm{~m}$ ) (Blicher et al. 2007). The difference in individual growth rates was only a fraction of the overall difference in secondary production at the population level, which we demonstrated in the present study. The higher production of the Kobbefjord population was a consequence of faster individual growth rates, higher reproductive output and higher density of sea urchins.

The joint estimate of annual macrobenthic carbon demand in Kobbefjord was higher than total macrobenthic carbon requirements in most high-Arctic habitats, and was in a range comparable to that of the macrozoobenthic community in the highly productive part of the North Bering and Chukchi Seas (Table 3, Fig. 8). Even though the estimates in Table 3 have been calculated by different methods and not all temporal and spatial variations have been captured, the scale of differences in carbon demand between Arctic sites are remarkable given the fact that the compared communities are in similar depth and temperature ranges (see subsection of 'Individual production' for details on temperature). Hence, the existence of areas with low macrobenthic activities in the Arctic may not be related directly to temperature. Instead, the available data, although limited, support the expectation that variations in ecosystem primary production and thus food availability for secondary producers are reflected in macrozoobenthic production and carbon demand in the Arctic region. However, benthic primary producers (micro- and macroalgae), advection and inputs from land might contribute significantly to food availability in coastal areas independent of pelagic primary production (e.g. Rysgaard \& Nielsen 2006). Hence, the apparent relation between macrozoobenthic carbon demand and pelagic primary production is only suggestive with respect to the underlying processes.

Given the reductions in seasonal sea ice cover in the Arctic in recent years (Serreze et al. 2007), one of the primary ecological effects is the changed light regime in the water column, leading to a longer productive season and higher level of primary production (Rysgaard et al. 1999, Wassmann et al. 2006, Arrigo et al. 2008). Hence, it has been argued that reductions in sea ice cover have the potential to reorganize benthicoriented ecosystems towards a higher dominance of pelagic processes (Grebmeier et al. 2006b). However, 
Table 3. Summary of available estimates of macrobenthic carbon demand and pelagic primary production from coastal and shelf areas in the Arctic and sub-Arctic. Superscript letters indicate the source of the estimate of primary production. No superscript indicates that estimates of both macrobenthic carbon demand and pelagic primary production are given in the same study. See illustration in Fig. 8

\begin{tabular}{|c|c|c|c|c|}
\hline Location & $\begin{array}{l}\text { Macrobenthic } \\
\text { carbon demand } \\
\left(\mathrm{g} \mathrm{C} \mathrm{m}^{-2} \mathrm{yr}^{-1}\right)\end{array}$ & $\begin{array}{l}\text { Depth } \\
\text { (m) }\end{array}$ & $\begin{array}{c}\text { Pelagic primary } \\
\text { production } \\
\left(\mathrm{g} \mathrm{C} \mathrm{m}^{-2} \mathrm{yr}^{-1}\right)\end{array}$ & Source \\
\hline North Bering \& Chukcki Seas & 51 & $19-53$ & $250-300$ & Grebmeier et al. (1989) \\
\hline Kobbefjord, West Greenland & 33 & $0-120$ & $75-160^{\mathrm{b}, \mathrm{i}, \mathrm{j}}$ & Present study \\
\hline Bering Sea & 25 & $6-161$ & $150-175^{\mathrm{e}}$ & Klages et al. (2004) \\
\hline Sørfjord, North Norway & $17^{\mathrm{a}}$ & $18-128$ & $105-132^{\mathrm{c}}$ & Nilsen et al. (2006) \\
\hline North Bering \& Chukcki Seas & $4-8$ & $19-53$ & 50 & Grebmeier et al. (1989) \\
\hline Kara Sea & $1-16$ & $10-68$ & $30-50^{\mathrm{h}}$ & Klages et al. (2004) \\
\hline NW Barents Sea & 3.3 & $80-240$ & $8-38^{\mathrm{d}, \mathrm{f}}$ & Piepenburg et al. (1995) \\
\hline Young Sound, NE Greenland & 5.4 & $0-40$ & $10^{\mathrm{g}}$ & Rysgaard \& Nielsen (2006) \\
\hline Young Sound, NE Greenland & 3.5 & $40-160$ & $10^{g}$ & Rysgaard \& Nielsen (2006) \\
\hline Laptev Sea & $3-10$ & $0-50$ & $7-25$ & Schmid et al. (2006) \\
\hline
\end{tabular}

the combination of data listed in Table 3 and illustrated in Fig. 8 indicate that the carbon requirements of macrobenthic communities in shallow ecosystems in the Arctic have the potential of increasing in concurrence with the level of primary production despite variations in physical characteristics. Thus, macrobenthic production, and carbon demand, on the shelves and in coastal areas in the high-Arctic may be expected to increase as a consequence of future reductions in seasonal sea ice cover.

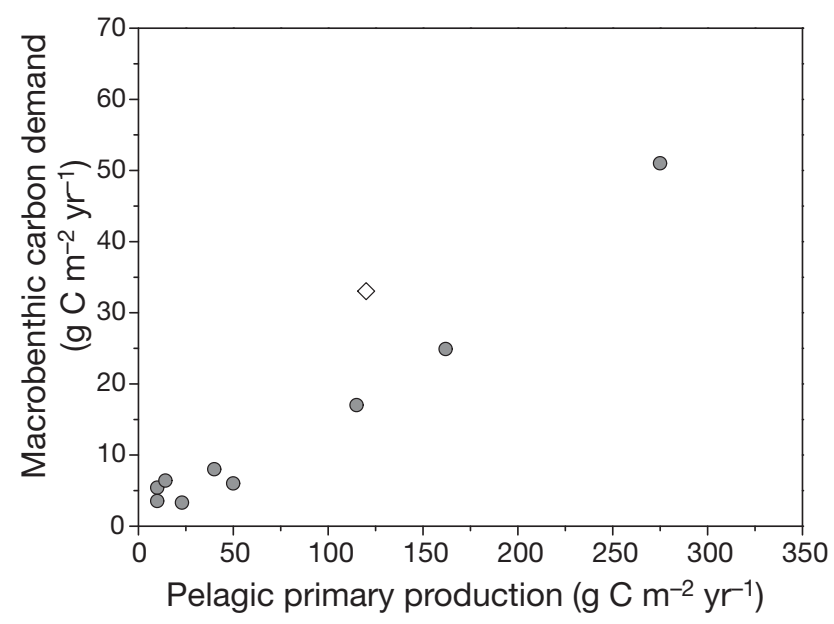

Fig. 8. Illustration of data presented in Table 3. Previously published estimates of annual macrozoobenthic carbon demand $(\circ)$ and the estimate in the present study $(\diamond)$ plotted against annual pelagic primary production. See Table 3 for references
Acknowledgements. We thank L. Heilman and F. Heinrich for technical assistance. A. Haxen is thanked for linguistic corrections. The authors were financially supported by the Commission for Scientific Research in Greenland (KVUG), the Ministry of Culture, Education and Churches (KIIP) and the Aage V. Jensen Charity Foundation. The project has received financial support from the Danish Energy Agency as part of the climate support program to the Arctic and is a contribution to the Nuuk Basic program.

\section{LITERATURE CITED}

ACIA (Arctic Climate Impact Assessment) (2005) Arctic climate impact assessment. Cambridge University Press, Cambridge

Arrigo KR, van Dijken G, Pabi S (2008) Impact of shrinking Arctic ice cover on marine primary production. Geophys Res Lett 35:L19603. doi:10.1029/2008GL035028

Blicher ME, Rysgaard S, Sejr MK (2007) Growth and production of sea urchin Strongylocentrotus droebachiensis in a high-Arctic fjord, and growth along a climatic gradient (64 to $77^{\circ}$ N). Mar Ecol Prog Ser 341:89-102

Brey T (1991) Population dynamics of Sterechinus antarcticus (Echinodermata: Echinoidea) on the Weddell Sea shelf and slope, Antarctica. Antarct Sci 3:251-256

Brey T (2001) Population dynamics in benthic invertebrates. A virtual handbook, Version 01.2. Available at: www.thomasbrey.de/science/virtualhandbook

Brey T, Pearse J, Basch L, McClintock J (1995) Growth and production of Sterechinus neumayeri (Echinoidea: Echinodermata) in McMurdo Sound, Antarctica. Mar Biol 124:279-292

Brockington S, Clarke A (2001) The relative influence of temperature and food on the metabolism of a marine invertebrate. J Exp Mar Biol Ecol 258:87-99

Clarke A (1988) Seasonality in the antarctic marine environment. Comp Biochem Physiol B 90:461-473

- Clarke A, Fraser K (2004) Why does metabolism scale with temperature? Funct Ecol 18:243-251 
Eilertsen HC, Taasen JP (1984) Investigations on the plankton community of Balsfjorden, northern Norway - the phytoplankton 1976-1978 - environmental factors, dynamics of growth, and primary production. Sarsia 69:1-15

Engelstoft J (2000) Omplantning af kammuslinger, Chlamys islandica, ved Nuuk. Teknisk Rapport, nr 30 Pinngortitaleriffik, Grønlands Naturinstitut, Nuuk

Gagnon P, Himmelman J, Johnson L (2004) Temporal variation in community interfaces: kelp-bed boundary dynamics adjacent to persistent urchin barrens. Mar Biol 144: 1191-1203

Grebmeier J, Feder H, McRoy C (1989) Pelagic-benthic coupling on the shelf of the northern Bering and Chuchi Seas. II. Benthic community structure. Mar Ecol Prog Ser 51: 253-268

> Grebmeier JM, Cooper LW, Feder HM, Sirenko BI (2006a) Ecosystem dynamics of the Pacific-influenced northern Bering and Chukchi Seas in the Amerasian Arctic. Prog Oceanogr 71:331-361

Grebmeier JM, Overland JE, Moore SE, Farley EV and others (2006b) A major ecosystem shift in the northern Bering Sea. Science 311:1461-1464

Hatcher A (1989) RQ of benthic marine invertebrates. Mar Biol 102:445-452

> Hegseth EN (1998) Primary production of the northern Barents Sea. Polar Res 17:113-123

> Heilmayer O, Brey T, Chiantore M, Cattaneo-Viettu R, Arntz W (2003) Age and productivity of the antarctic scallop Adamussium colbecki, in Terra Nova Bay (Ross Sea, Antarctica). J Exp Mar Biol Ecol 288:239-256

Heilmayer O, Brey T, Pörtner H (2004) Growth efficiency and temperature in scallops: a comparative analysis of species adapted to different temperatures. Funct Ecol 18:641-647

> Himmelman J, Cardinal A, Bourget E (1983) Community development following removal of urchins, Strongylocentrotus droebachiensis, from the rocky subtidal zone of the St. Lawrence Estuary, eastern Canada. Oecologia 59:27-39

> Hop H, Pearson T, Hegset E, Kovacs K and others (2002) The marine ecosystem of Kongsfjord, Svalbard. Polar Res 21: $167-208$

Jensen M (1969) Age determination of echinoids. Sarsia 37: 41-44

Johannessen O (1973) Age determination in Chlamys islandica. Astarte 6:15-20

Klages M, Boetius A, Christensen J, Deubel H, Piepenburg D, Schewe I, Soltwedel T (2004) The benthos of Arctic seas and its role for the organic carbon cycle at the seafloor. In: Stein R, Macdonald R (eds) The organic carbon cycle in the Arctic Ocean. Springer-Verlag, Berlin

> Mamelona J, Pelletier E (2005) Green urchin as a significant source of fecal particulate organic matter within nearshore benthic ecosystems. J Exp Mar Biol Ecol 314:163-174

Marquardt D (1963) An algorithm for least squares estimation of non-linear parameters. SIAM J Appl Math 11:431-441

Meidel S, Scheibling R (1999) Effects of food type and ration on reproductive maturation and growth of the sea urchin Strongylocentrotus droebachiensis. Mar Biol 134:155-166

Menard HW, Smith SM (1966) Hypsometry of ocean basin provinces. J Geophys Res 71:4305-4325

Mikkelsen D, Rysgaard S, Glud R (2008a) Microalgal composition and primary production in Arctic sea ice: a seasonal study from Kobbefjord (Kangerlauarsunnguaq), West Greenland. Mar Ecol Prog Ser 368:65-74

Mikkelsen DM, Rysgaard S, Mortensen J, Retzel A and others (2008b) Nuuk Basic: The MarineBasic Programme 2007. In: Jensen LM, Rasch M (eds) Nuuk ecological research operations, 1st annual report, 2007. Danish Polar Centre, Danish Agency for Science, Technology and Innovation, Ministry of Science, Technology and Innovation, Copenhagen
Miller R, Mann K (1973) Ecological energetics of the seaweed zone in a marine bay on the Atlantic coast of Canada. III. Energy transformations by sea urchins. Mar Biol 18: 99-114

Nielsen J (1994) En gennemgang af grønne søpindsvins fiskeribiologi relateret til kommerciel udnyttelse i Grønland. Danmarks Fiskeri- og Havundersøgelser, Charlottenlund

Nilsen M, Pedersen T, Nilssen E (2006) Macrobenthic biomass, productivity $(P / B)$ and production in a high-latitude ecosystem, North Norway. Mar Ecol Prog Ser 321:67-77

Oganesyan SA (1998) Reproductive cycle of the echinoid Strongylocentrotus droebachiensis in the Barents Sea. In: Mooi R, Telford M (eds) Echinoderms: San Francisco. Balkema, Rotterdam, p 765-768

Pearse J, Pearse V (1975) Growth zones in the echinoid skeleton. Am Zool 15:731-753

Pedersen S (1994) Population parameters of the Iceland scallop (Chlamys islandica (Müller)) from West Greenland. J Northwest Atl Fish Sci 16:75-87

> Piepenburg D, Blackburn T, van Dorrien C, Gutt J and others (1995) Partitioning of benthic community respiration in the Arctic (northwestern Barents Sea). Mar Ecol Prog Ser 118:199-213

Pörtner H, Storch D, Heilmayer O (2005) Constraints and tradeoffs in climate-dependent adaption: energy budgets and growth in a latitudinal cline. Sci Mar 69:271-285

Richards F (1959) A flexible growth model for empirical use. J Exp Bot 10:290-300

Rubach S, Sundet J (1987) Ressurskartlegging av haneskjell (Chlamys islandica [OF Müller]) ved Jan Mayen og i Svalbardsonen i 1986. Fiskeresursbiologi, Institut for Fiskerifag, Universitetet i Tromsø, Tromsø

Rysgaard S, Nielsen TG (2006) Carbon cycling in a high-arctic marine ecosystem-Young Sound, NE Greenland. Prog Oceanogr 71:426-445

> Rysgaard S, Nielsen T, Hansen B (1999) Seasonal variation in nutrients, pelagic primary production and grazing in a high-arctic coastal marine ecosystem, young Sound, Northeast Greenland. Mar Ecol Prog Ser 179:13-25

Rysgaard S, Arendt KE, Frederiksen MS, Egevang C and others (2008) Nuuk Basic: The MarineBasic Programme 2005-2006. In: Jensen LM, Rasch M (eds) Nuuk ecological research operations, 1st annual report, 2007. Danish Polar Centre, Danish Agency for Science, Technology and Innovation, Ministry of Science, Technology and Innovation, Copenhagen

Sakshaug E (2004) Primary and secondary production in the Arctic seas. In: Stein R, Macdonald R (eds) The organic carbon cycle in the Arctic Ocean. Springer-Verlag, Berlin, p 57-81

Schmid MK, Piepenburg D, Golikov AA, von Juterzenka K, Petryashov VV, Spindler M (2006) Trophic pathways and carbon flux patterns in the Laptev Sea. Prog Oceanogr 71: 314-330

Sejr M, Sand M, Jensen K, Petersen J, Christensen P, Rysgaard S (2002) Growth and production of Hiatella arctica (Bivalvia) in a high-Arctic fjord (Young Sound, Northeast Greenland). Mar Ecol Prog Ser 244:163-169

Sejr M, Petersen J, Jensen K, Rysgaard S (2004) Effects of food concentration on clearance rate and energy budget of the Arctic bivalve Hiatella arctica (L) at subzero temperature. J Exp Mar Biol Ecol 311:171-183

Serreze MC, Holland MH, Stroeve J (2007) Perspectives on the Arctic's shrinking sea-ice cover. Science 315:1533-1536

Smidt E (1979) Annual cycles of primary production and of zooplankton at southwest Greenland. Greenland Bioscience 1:1-53 
Sugden L, Driver E, Kingsley M (1981) Growth and energy consumption of captive mallards. Can J Zool 59: $1567-1570$

Sundet J, Vahl O (1981) Seasonal changes in the dry weight and biochemical composition of the tissues of sexually mature and immature Iceland scallops, Chlamys islandica. J Mar Biol Assoc UK 61:1001-1010

Vahl O (1978) Seasonal changes in oxygen consumption of the Iceland scallop (Chlamys islandica [O.F. Müller]) from $70^{\circ} \mathrm{N}$. Ophelia 17:143-154

Vahl O (1981) Energy transformations by the Iceland scallop, Chlamys islandica (O.F. Müller) from $70^{\circ}$ N. I. The age-specific energy budget and net growth efficiency. J Exp Mar Biol Ecol 53:281-296

Wallace J, Reinsnes T (1985) The significance of various environmental parameters for growth of the Iceland scallop,

Editorial responsibility: Hans Heinrich Janssen, Oldendorf/Luhe, Germany
Chlamys islandica (Pectinidae) in hanging culture. Aquaculture 44:229-242

Walsh JJ, Dieterle DA (1994) $\mathrm{CO}_{2}$ cycling in the coastal ocean. I. A numerical-analysis of the southeastern Bering Sea with applications to the Chukchi Sea and the northern Gulf-ofMexico. Prog Oceanogr 34:335-392

Wassmann P, Slagstad D (1991) Annual dynamics of carbon flux in the Barents Sea: preliminary results. Nor Geol Tidsskr 71:231-234

Wassmann P, Slagstad D (1993) Seasonal and annual dynamics of particulate carbon flux in the Barents Sea-a model approach. Polar Biol 13:363-372

Wassmann P, Slagstad D, Riser C, Reigstad M (2006) Modelling the ecosystem dynamics of the Barents Sea including the marginal ice zone. II. Carbon flux an interannual variability. J Mar Syst 59:1-24

Submitted: November 27, 2008; Accepted: February 16, 2009 Proofs received from author(s): April 16, 2009 